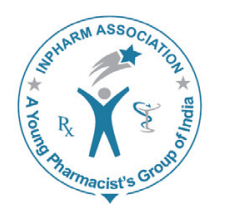

\title{
In silico Design, Synthesis and Pharmacological screening of Quinazolinones as NMDA receptor antagonists for Anticonvulsant activity: Part II
}

\author{
Amit G. Nerkar ${ }^{* 1}$, Megha Sahu², Shweta Valvi ${ }^{3}$ and Sanjay D. Sawant ${ }^{1}$ \\ ${ }^{1}$ Department of Pharmaceutical Chemistry, ${ }^{2}$ Senior Research Fellow and ${ }^{3}$ Post Graduate Research Fellow \\ Smt. Kashibai Navale College of Pharmacy, Kondhwa, Pune-48, India.
}

\begin{abstract}
Background: N-methyl-D-Aspartate (NMDA) receptor plays a main role in eliptogenisis and its inhibition has therapeutic significance in development of anticonvulsants. Prioritized quinazolinone molecules were synthesized, evaluated in vivo by AOT and then for anticonvulsant activity in NMDA induced convulsion model. Method: In silico Screening of prioritized molecule was done by biological activity predictions, partition coefficient predictions (Log P), molecular docking on NMDA receptors, in silico ADME predictions using PASS server and mol inspiration software, V Life MDS 4.3 software and Pre ADMET server respectively. This gave biological activity (BA) score for anticonvulsant activity and predicted Log $P$ values $(p \log P)$. The standard Log P required for anticonvulsant activities being more than 2.00, therefore molecules were also prioritized based on this $\mathrm{p}$ Log P criteria. Docking showed results of antagonism in silico as compared with Memnatine and molecules were prioritized for synthesis based on this criteria. Result: Quinazolinone molecules were prioritized based upon docking score, $\mathrm{ADME}$ and $\mathrm{BA}$ score, synthesized and pharmacologically screened for anticonvulsant activity. Conclusion: $\mathrm{SMMB}_{1}, \mathrm{SMMB}_{2}, \mathrm{SMMB}_{3}$ showed the prominent anticonvulsant activity as compared with memantine used as standard for in vivo anticonvulsant activity. The compounds can serve as anticonvulsant Leads through NMDA antagonism.
\end{abstract}

Key words: Anticovulsant, Mol inspiration, NMDA, PASS, Pre ADMET, Quinazolinone.

\section{INTRODUCTION}

NMDA receptors in the mammalian central nervous system are only formed by combinations of NR1 and NR2 subunits, NR1 subunit express glycine and NR2 express glutamate. The NR2 subunit family is in turn divided into four individual subunit types: NR2A, NR2B, NR2C,

\begin{tabular}{|c|c|}
\hline \multicolumn{2}{|c|}{ Access this article online } \\
\hline Journal Sponsor & \multirow[b]{2}{*}{$\begin{array}{l}\text { Website: } \\
\text { www.jyoungpharm.org }\end{array}$} \\
\hline \multirow{2}{*}{ www.phcog net } & \\
\hline & $\begin{array}{l}\text { DOI: } \\
\text { 10.5530/jyp.2015.4.4 }\end{array}$ \\
\hline
\end{tabular}

and NR2D. In part-I of this series of research papers we published the data of some quinazolinones attached with oxazepinone rings as NMDA receptor antagonists for anti-convulsant activity which can serve as anti-convulsant "leads" with activity of $70 \%$ as compared with memantine, apotent anticonvulsant agent. In continuation of our work on discovery of potent NMDA receptor antagonists from quinazolinone series, ${ }^{1-3}$ we here report the quinazolinones with thiobarbituric acid and barbituric acid moieties as potent NMDA receptor antagonists for anticonvulsant activity. This research work consists of in silico screening, synthesis, characterization and pharmacological screening of some Quinazolinones containing barbituric acid and

\footnotetext{
*Address for correspondence:

Dr. Amit G. Nerkar, Associate Professor in Medicinal Chemistry, Department of Pharmaceutical and Medicinal Chemistry, STES's Smt. Kashibai Navale College of Pharmacy, Kondhwa budhrukh, Pune-48, M.S. India.E-mail: amit.nerkar@sinhgad.edu
} 

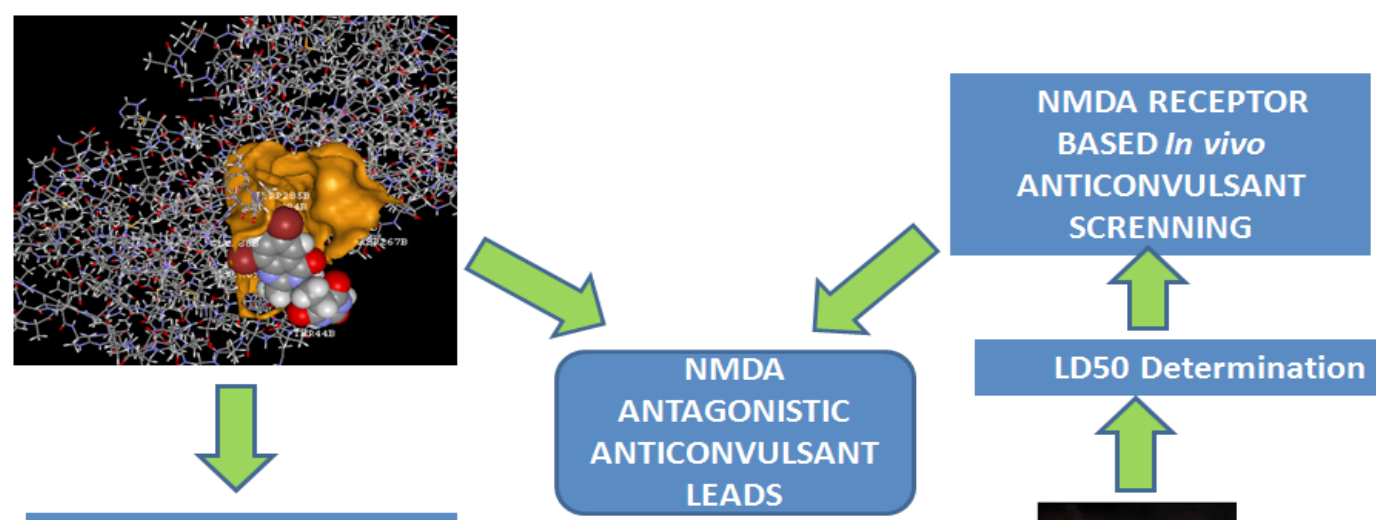

In silico ADME

PREDICTIONS
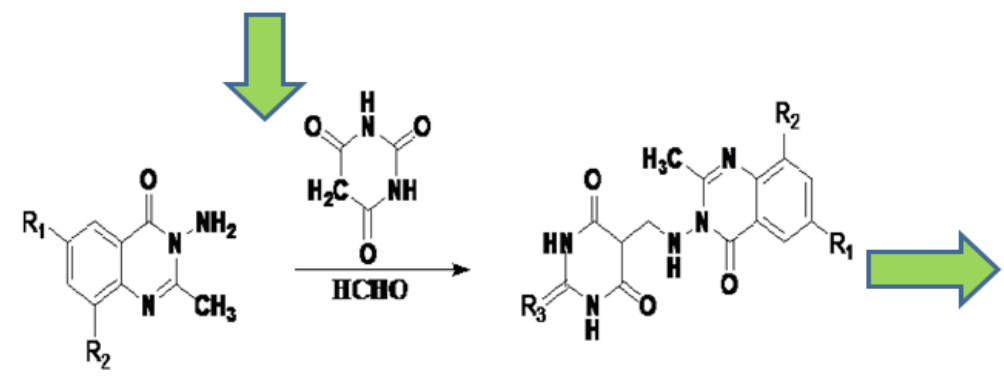

LD50 Determination

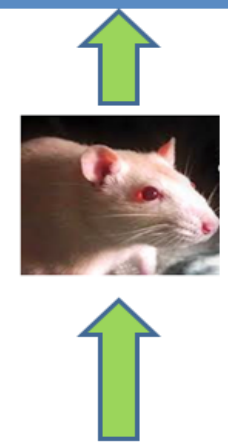

PHARMACOLOGICAL SCREENING

Graphical Abstract

thiobarbituric acid moieties as NMDA receptor antagonists for anticonvulsant activity. With a series of molecules as described (series $\mathrm{SMMB}_{1-3}$ ) were in silico prioritized by molecular docking to obtain antagonism scores using Vlife sciences MDS 4.3 drug design software. Pre ADMET software was used for prioritization of molecules based upon ADME properties. Based on which Caco-2, MDCK, HIA (Human Intestinal Absorption), PBB (Plasma Protein Binding), BBB (penetration in Blood Brain Barrier) for the molecules in silico, these prioritized molecules were first synthesized and then characterized by TLC, IR, ${ }^{1} \mathrm{HNMR}$ and melting point. Caco-2 permeability is a determinant of apparent permeability, MDCK permeability value was considered for apparent permeability, HIA value is determinant of the apparent Human Intestinal absortion. $\mathrm{PBB}$ is determinant of binding of drug molecule to the plasma proteins. BBB values are determinant and essential for the molecules which are designed to be active on central nervous system. Prioritization was based on criteria of violation of the optimum upper limit of ranges in case of in silico ADME predictions and comparison with antagonism scores of Memantine used as standard for docking trials. Only these sufficient ADME predictions were considered during in silico predictions. Ranges of ADME predictions and obtained values are shown in Table 1. In silico $\mathrm{p}$ Log $P$ values were also obtained to prioritize molecules based on $\log \mathrm{P}$ criteria. In vivo pharmacological evaluation was done by Acute Oral toxicity (AOT) followed by inhibition of NMDA induced convulsions mechanistic model for anticonvulsant activity. Acute Oral Toxicity (AOT) was carried to determine $\mathrm{LD}_{50}$ of the prioritized molecules according to OECD guideline 453. Further molecules were evaluated from 700 to $2000 \mathrm{mg} / \mathrm{kg}$ dose for AOT study. On the basis of AOT the dose was decided for anticonvulsant activity. Prioritized molecules were found to have potency between $40-70 \%$ as compared with Memantine used as standard in in silico and in vivo studies. Prioritized molecules are shown in Figure 1.

\section{MATERIAL AND METHODS}

\section{In silico ${ }^{[4,5]}$}

Biological Activity Scores

These were obtained from PASS server online for biological activity prediction.

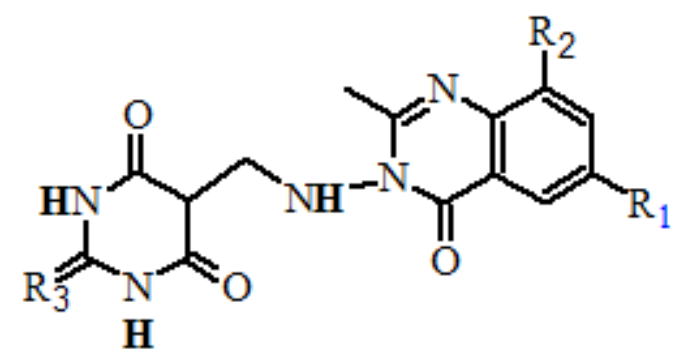

Figure 1: Structure of prioritized molecules 


\begin{tabular}{|c|c|c|c|c|c|c|c|}
\hline \multirow{2}{*}{$\begin{array}{c}\text { Compound } \\
\text { Standard ranges }\end{array}$} & \multirow[b]{2}{*}{ BAS } & \multirow[b]{2}{*}{ pLog $p$} & \multicolumn{5}{|c|}{ ADME Predictions } \\
\hline & & & $\begin{array}{c}\mathrm{Caco}_{2} \\
\text { 4-70 nm/sec }\end{array}$ & $\begin{array}{l}\text { MDCK } \\
25-500 \\
\mathrm{~nm} / \mathrm{sec}\end{array}$ & $\begin{array}{c}\text { BBB } \\
\sim 1.00\end{array}$ & $\begin{array}{c}\text { HIA } \\
20-70 \%\end{array}$ & $\begin{array}{l}\text { PPB } \\
90 \%\end{array}$ \\
\hline $\mathrm{SMMB}_{1}$ & 0.883 & -1.74 & 19.79 & 0.15 & 0.05196 & 93.08 & 93.02 \\
\hline $\mathrm{SMMB}_{2}$ & 0.965 & -1.12 & 20.46 & 0.436 & 0.11710 & 93.96 & 67.79 \\
\hline $\mathrm{SMMB}_{3}$ & 0.848 & -1.04 & 19.70 & 0.48 & 0.059729 & 95.12 & 83.14 \\
\hline Memantine & 0.890 & 3.500 & 25.89 & 0.078 & 1.5905 & 94.38 & 98.89 \\
\hline
\end{tabular}

\begin{tabular}{|c|c|c|c|c|}
\hline Compound code & $\begin{array}{c}\text { Autodock } \\
\text { Docking Score }\end{array}$ & Amino Acid & $\mathrm{H}$ - bonding & $\begin{array}{c}\text { Vlife MDS } \\
\text { Docking Score }\end{array}$ \\
\hline $\begin{array}{c}\text { Standard } \\
\text { (Memantine) }\end{array}$ & -13.63 & $\begin{array}{c}\text { HIS127B, GLY128B, } \\
\text { ASP265B }\end{array}$ & No & -32.38 \\
\hline SMMBᄀ1 & -8.38 & $\begin{array}{l}\text { HIS127B,SER131B, } \\
\text { ILE133B }\end{array}$ & - & -54.34 \\
\hline SMMB2 & -8.89 & $\begin{array}{c}\text { THR103B, GLY128B, } \\
\text { MET132B }\end{array}$ & 1 & -61.23 \\
\hline SMMB3 & -9.78 & $\begin{array}{c}\text { THR44B, ASP102B, } \\
\text { HIS127B }\end{array}$ & 2 & -56.00 \\
\hline Barbituric acid & - & $\begin{array}{l}\text { HIS127B, GLY128B, } \\
\text { THR266B }\end{array}$ & 3 & -31.81 \\
\hline Thiobarbituric acid & - & $\begin{array}{c}\text { HIS127B, ASP265B, } \\
\text { GLU284B }\end{array}$ & 2 & -33.34 \\
\hline
\end{tabular}

pLogP predictions ${ }^{5}$

Log P of a compound should be greater than 2.00 for compound to cross the blood brain barrier. pLog P values were also obtained to prioritize molecules based on Log $\mathrm{P}$ value. Scores were obtained by molinspiration software. Scores are given in Table 1.

\section{ADME Predictions ${ }^{6}$}

The in silico ADME parameters and their ranges used for prioritization are mentioned under each ADME property (Table 1). These were obtained in silico from Pre ADMET Server online.

\section{Molecular Docking Studies}

Docking study was performed on Vlife MDS 4.3 Drug design software and Auto dock 1.4.5. Marvin Bean and Chemdraw 12 software were used to draw molecular structures, for conversion of $2 \mathrm{D}$ structure to mole files. 2D structure of ligand were prepared in Marvin sketch and converted to 3D by Vlife sciences MDS 4.3 Drug Design Software. The 3D structure was stabilized by minimizing the energy using molecular mechanics followed by Merck Molecular Force Field (MMFF). Conformational changes in compound were obtained by Monte Carlo method. All the Conformers were then energetically minimized up to the rms gradient of 0.001 . The PDB of NMDA receptor subunit NR2B was obtained from protein database with www.rscb.org. The PDB was subjected for docking study. All software scores are listed in Table 2.

\section{Chemistry}

General procedure for synthesis of the target compound $\left(S M M B_{1-3}\right)$ All chemicals were procured from, SD Fine, Spectrochem, Sigma Aldrich and Merck.

Apparatus: VEEGO - VMP I melting point apparatus was used to determine melting point. SHIMADZU Affinity-I spectrophotometer was for recording the IR spectrum. ${ }^{1} \mathrm{H}$ NMR were recorded at Diya labs Mumbai on $400 \mathrm{MHz}$ Spectrophotometer facility, chemical shifts $(\delta)$ are reported in parts per million (ppm) with $\mathrm{CDCl}_{3}$ and DMSO as solvent for NMR. TMS was used as internal standard for NMR. Splitting of signals is represented by s (singlet), d (doublet), $\mathrm{t}$ (triplet), q (quartet), $\mathrm{m}$ (multiplates). Thin layer chromatography (TLC) was performed on Merk GF $_{254}$ precoated aluminium plate.

General synthesis scheme of the target compound ${ }^{7-11}\left(\mathrm{SMMB}_{1-3}\right)$ To a solution of barbituric acid $(0.01 \mathrm{~mol}) /$ thiobarbituric acid $(0.01 \mathrm{~mol})$ in methanol as solvent, formaldehyde $(0.02$ $\mathrm{mol})$ and 3-amino-2-methylquinazolin-4(3H)-one (0.02 mol) were added drop wise. The reaction mixture was refluxed on a steam bath for $4 \mathrm{hr}$. The excess of solvent was distilled off. The solid thus obtained was washed with water and recrystallized from acetone. Impurities were removed by column chromatography. ${ }^{6,7}$

Synthetic scheme is given in (Figure 2). 
<smiles>[R]c1cc([R2])c2nc(C)n(N)c(=O)c2c1</smiles>

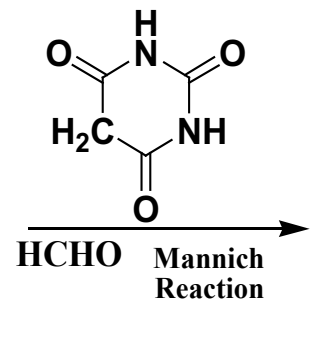<smiles>[R]c1cc([R2])c2nc(C)n(NCC3C(=O)NC(=[R])NC3=O)c(=O)c2c1</smiles>

Figure 2: Synthetic scheme of prioritized molecules

\begin{tabular}{ccccc}
\hline $\begin{array}{c}\text { Table 3: Synthesized Compounds } \\
\begin{array}{c}\text { Compound } \\
\text { Code }\end{array}\end{array}$ & R1 & R2 & R3 & $\begin{array}{c}\text { Melting Point } \\
{ }^{\circ} \mathbf{C}\end{array}$ \\
\hline SMMB $_{1}$ & $\mathrm{Br}$ & $\mathrm{H}$ & $\mathrm{O}$ & $105-110$ \\
$\mathrm{SMMB}_{2}$ & $\mathrm{Br}$ & $\mathrm{Br}$ & $\mathrm{S}$ & $100-105$ \\
$\mathrm{SMMB}_{3}$ & $\mathrm{Br}$ & $\mathrm{Br}$ & $\mathrm{O}$ & $105-115$ \\
\hline
\end{tabular}

R1=Bromine; R2=Bromine/Hydrogen; R3=Sulfer/Oxygen.

Synthesis of 2(methyl) 6-Bromo-3-amino(-5-methyl (Thiobarbituryl) quinazoline-4(3H) one $\left(\mathrm{SMMB}_{1}\right):{ }^{7,8}$ To a solution of thiobarbituric acid $(0.01 \mathrm{~mol})$ in methanol as solvent, formaldehyde $(0.02 \mathrm{~mol})$ and 6 - bromo-3-amino2 -methylquinazolin-4(3H)-one $(0.02 \mathrm{~mol})$ was added drop wise. The reaction mixture was refluxed on a steam bath for $4 \mathrm{hr}$. The excess of solvent was distilled off. Obtained solid was washed with water and recrystallized from acetone. Impurities were removed by column chromatography.

2(methyl) 6-Bromo-3-amino(-5- methyl (Thiobarbituryl) quinazol ine $-4(3 \mathrm{H})$ one $(\mathrm{SMMB})$

$\%$ Yield: 55\%, Molecular Formula: $\mathrm{C}_{14} \mathrm{H}_{12} \mathrm{BrN}_{5} \mathrm{O}_{3} \mathrm{~S}$, Melting Point:100-105 ${ }^{\circ} \mathrm{C}$, Molecular wt:408, $\mathrm{R}_{\mathrm{f}}: 0.5$ (Hexane:Ethyl acetate 70: 30). I.R. ( $\left.\mathrm{KBr}, \mathrm{cm}^{-1}\right): 1679.55$ (C=O, Str., M). 499.47(Ar., C=C, Str.), 2260 (S st.), 1374.03 (C-H, Str.), 2942.84(C-H str.), 3379 ( $2^{0} \mathrm{~N}-\mathrm{H}$ str.) ${ }^{1} \mathrm{H}$ NMR (300 MHz, $\left.\mathrm{CDCl}_{3}\right) \delta[\mathrm{ppm}]: 7.71-7.79(\mathrm{~d}, 2 \mathrm{H}, \mathrm{CH}, \mathrm{J}=0.52) ; 8.1(\mathrm{H}, \mathrm{CH}$, $\mathrm{J}=0.029) ; 2.51\left(\mathrm{~s}, 1 \mathrm{H}, \mathrm{CH}_{3} \mathrm{~J}=0.805\right) ; 2.04\left(\mathrm{NHs}, \mathrm{H}, \mathrm{CH}_{2}\right.$, $\mathrm{J}=0.37) ; 11.59-11.95$ (d, 2H, NH, J=1.39).

Synthesis of 2(methyl), 6, 8-Bromo-3-amino(-5-methyl (Thioarbituryl) quinazoline-4(3H) one $\left(S M M B_{2}\right)$

To a solution of thiobarbituric acid $(0.01 \mathrm{~mol})$ in methanol as solvent, formaldehyde (0.02 mol) and 6, 8-dibromo-3amino-2-methylquinazolin-4(3H)-one ( $0.02 \mathrm{~mol})$ was added drop wise. The reaction mixture was refluxed on a steam bath for $4 \mathrm{hr}$. The excess of solvent was distilled off. Obtained solid was washed with water and recrystallized from acetone. Impurities were removed by column chromatography.

2(methyl), 6, 8-Bromo-3-amino(-5-methyl (Thioarbituryl) quinazoline- $4(3 \mathrm{H})$ one $\left(\mathrm{SMMB}_{2}\right)$

$\%$ Yield: 60\%, Molecular Formula: $\mathrm{C}_{14} \mathrm{H}_{11} \mathrm{Br}_{2} \mathrm{~N}_{5} \mathrm{O}_{3}$ S Melting Point:100-105 ${ }^{\circ} \mathrm{C}$, Molecular wt:489, Rf: 0.5 (Hexane:Ethyl acetate 70: 30). I.R. $\left(\mathrm{KBr}, \mathrm{cm}^{-1}\right): 1679.55$ (C=O, Str.). 660 (Br st.), 499.47(Ar., C=C, Str.),2260 (S st.), 1374.03 (C-H, Str..), 2942.84(C-H str.), 3379 ( $2^{0} \mathrm{~N}-\mathrm{H}$ str.) ${ }^{1} \mathrm{H}$ NMR (300 $\left.\mathrm{MHz}_{\mathrm{CDCl}}\right) \delta[\mathrm{ppm}]: 8.17-8.3(\mathrm{~d}, 2 \mathrm{H}, \mathrm{CH}, \mathrm{J}=0.16) ; 2.62$ $\left(\mathrm{H}, \mathrm{CH}_{3} \mathrm{~J}=0.16\right) ; 10.96(\mathrm{~s}, 1 \mathrm{H}, \mathrm{NH}, \mathrm{J}=1.13) ; 11.92-12.69(\mathrm{~d}$, $\mathrm{H}, \mathrm{NH}, \mathrm{J}=2.24)$.

Synthesis of 2(methyl), 6, 8-Bromo-3- amino (-5-methyl (barbituryl) quinazol ine- $4(3 \mathrm{H})$ one $\left(\mathrm{SMMB}_{3}\right)$

To a solution of barbituric acid $(0.01 \mathrm{~mol})$ in methanol as solvent, formaldehyde (0.02 mol) and 6, 8-dibromo3-amino -2-methylquinazolin-4(3H)-one $(0.02 \mathrm{~mol})$ was added drop wise. The reaction mixture was refluxed on a steam bath for $4 \mathrm{hr}$. The excess of solvent was distilled off. Obtained solid was washed with water and recrystallized from acetone. Impurities were removed by column chromatography.

2(methyl), 6, 8-Bromo-3-amino(-5-methyl (barbituryl) quinazoline $-4(3 \mathrm{H})$ one $\left(\mathrm{SMMB}_{3}\right)$

$\%$ Yield: 60\%, Molecular Formula: $\mathrm{C}_{14} \mathrm{H}_{11} \mathrm{Br}_{2} \mathrm{~N}_{5} \mathrm{O}_{4}$, Melting Point:105-115 ${ }^{\circ} \mathrm{C}$, Molecular wt:473, Rf: 0.5 (Hexane:Ethyl acetate 70: 30). I.R. (KBr, cm$\left.{ }^{-1}\right): 1710$ (C=O, Str.). 680 (Br st.), 499.47(Ar., C=C, Str.),2260 (S st.),1374.03 (C-H, Str..), 2942.84(C-H str.), 3600 ( $2^{0} \mathrm{~N}-\mathrm{H}$ str.) ${ }^{1} \mathrm{H}$ NMR (300 MHz, $\left.\mathrm{CDCl}_{3}\right) \delta[\mathrm{ppm}]: 8.17-8.34(\mathrm{~d}, 2 \mathrm{H}, \mathrm{CH}, \mathrm{J}=0.009) ; 2.61(\mathrm{~S}$, $\left.\mathrm{H}, \mathrm{CH}_{3,} \mathrm{~J}=0.037\right) ; 9.65$ (s, 1H, NH J=1.36); $4.35\left(\mathrm{~S}, \mathrm{CH}_{2}\right.$, $\mathrm{J}=0.34), 10.11-10.24(\mathrm{~d}, \mathrm{H}, \mathrm{NH}, \mathrm{J}=0.17)$.

\section{Pharmacology Screening ${ }^{11-16}$}

Albino mice of either sex weighing between 20-25 gm, obtained from National Institute of Biomedical Sciences, Pune, India, were used in the present study. Animals were kept in wire-mesh cages under the laboratory conditions 
Nerkar, et al.: In silico Screening, Synthesis and Pharmacological Screening of Quinazolinones

\begin{tabular}{|c|c|c|c|c|}
\hline Code & $300 \mathrm{mg} / \mathrm{kg}$ & $700 \mathrm{mg} / \mathrm{kg}$ & $1000 \mathrm{mg} / \mathrm{kg}$ & $2000 \mathrm{mg} / \mathrm{kg}$ \\
\hline $\mathrm{SMMB}_{1}$ & Safe & Safe & Safe & Safe \\
\hline $\mathrm{SMMB}_{2}$ & Safe & Safe & ----- & ---- \\
\hline $\mathrm{SMMB}_{3}$ & Safe & Safe & Safe & ----- \\
\hline \multicolumn{5}{|c|}{ Table 5: It shows series $\mathrm{SMMB}_{1-3}$ evaluated at dose $2000 \mathrm{mg} / \mathrm{Kg}$} \\
\hline $\mathrm{SMMB}_{1}$ & 6 & 5 & 90 & 16.66 \\
\hline $\mathrm{SMMB}_{2}$ & 6 & 4 & 85 & 33.33 \\
\hline $\mathrm{SMMB}_{3}$ & 6 & 5 & 90 & 16.66 \\
\hline Memantine & 6 & 0 & 0 & 100 \\
\hline
\end{tabular}

Table 6: It shows \% Death and \% Inhibition of standard (Memantine) and control (NMDA)

$\begin{array}{ccccc}\text { Compound Code } & \text { No. of Animals } & \text { No. of dead Animals } & \% \text { Death } & \% \text { Inhibition } \\ \begin{array}{c}\text { Standard } \\ \text { (Memantine) }\end{array} & 6 & 0 & 0 & 100 \\ \text { Control (NMDA) } & 6 & 6 & 100 & 0\end{array}$

$\left(23 \pm 2^{\circ} \mathrm{C}\right), 12 \mathrm{~h}$ light. Animals were provided with food (Hindustan Lever Ltd. Mumbai) and water for $24 \mathrm{hrs}$ period before testing in a constant light-dark cycle. During the period of the experiment, the general behaviour of the animal was normal. The homogenous suspension of the test compounds and the standard drugs (Memantine) were prepared in tween 20 or tween 80 and distilled water (1:9 ML). Appropriate dose of NMDA was prepared in water.

\section{Acute oral toxicity (AOT) Studies ${ }^{11}$}

Acute oral toxicity was performed for determining the $\mathrm{LD}_{50}$ of compounds. This experiment was performed under the OECD guideline 453 adopted: $7^{\text {th }}$ September 2009. ${ }^{10}$ According to OECD guidelines, all animals are given with dose of $2000 \mathrm{mg} / \mathrm{Kg}$ and observed for $4 \mathrm{hrs}$ and then after 24 hours for salivation, awareness, motor activity, muscle tone etc. After 24 hour mortality was observed in animals. The test procedure was used to minimize the number of animals required for estimation of acute oral toxicity of compound as per OECD guidelines. Signs of toxicity were assured by $\mathrm{LD}_{50}$ and confidence interval. AOT study data shown in Table 4.

Acute Oral Toxicity (AOT) studies were carried out on 6 groups of animal i.e. Swiss albino mice according to OECD guideline 453. Test compounds $\left(\mathrm{SMMB}_{1-3}\right)$ were administered orally to albino mice and mice were observed for 24 hrs. All three test compounds $\left(\mathrm{SMMB}_{1-3}\right)$ were observed to be safe at dose of $2000 \mathrm{mg} / \mathrm{Kg}$.

\section{Anticonvulsant activity (Inhibition of NMDA induced convulsion) ${ }^{13-16}$}

NMDA can precipitate convulsions in patients with seizure disorders. The compound is regarded as a NMDA synthesis inhibitor. Tonic Clonic seizures induced in mice are antagonized by anticonvulsant agents. ${ }^{11,12}$ The animals were divided into three groups. Each group contained six mice of either sex having 20-28 gm weight. The test groups received a series of synthesized compound $\left(\mathrm{SMMB}_{1-3}\right)$ and at appropriate doses based upon its individual $\mathrm{LD}_{50}$ values. The standard group received (Memantine $10 \mathrm{mg} / \mathrm{kg}$ ) by oral or subcutaneous administration. Controls received the vehicle only. After 60 minutes subcutaneously (s.c) or animals were injected with dose of $125 \mathrm{mg} / \mathrm{kg}$ NMDA (N-methyl-Daspartate) intraperitonial. The occurrence of clonic seizure, ${ }^{15}$ tonic seizures \& death was recorded at three dose levels of the test compound. Activity results are given in Table 5, 6, 7 .

Albino mice of either sex (weighing about 25-30 gm) were used in study in which memantine was used as standard at a dose of $10 \mathrm{mg} / \mathrm{Kg}$ by oral or subcutaneous administration. Control group received NMDA of dose $125 \mathrm{mg} / \mathrm{Kg}$ by intraperitoneal route (I.P.) and all test groups received test compounds $\left(\mathrm{SMMB}_{1-3}\right)$ orally. Based upon their AOT studies $\mathrm{SMMB}_{3}$ was administered orally at a dose of 50-150 $\mathrm{mg} / \mathrm{Kg}$ body weight $30 \mathrm{~min}$ before to start the experiment. After 30 minute animals received NMDA at a dose of 125 $\mathrm{mg} / \mathrm{Kg}$ intraperitoneal. ${ }^{16}$

During the next 120 minutes the occurrence of clonic seizures, tonic seizures \& death was recorded at three dose high medium and low doses respectively. Time for inhibition of convulsions was observed and recovered (Table 4).

\section{RESULT AND DISCUSSION}

\section{In silico Studies}

Compounds with the code $\mathrm{SMMB}_{1-3}$ shown to have BAS score is $0.883,0.965$ and 0.848 respectively which 


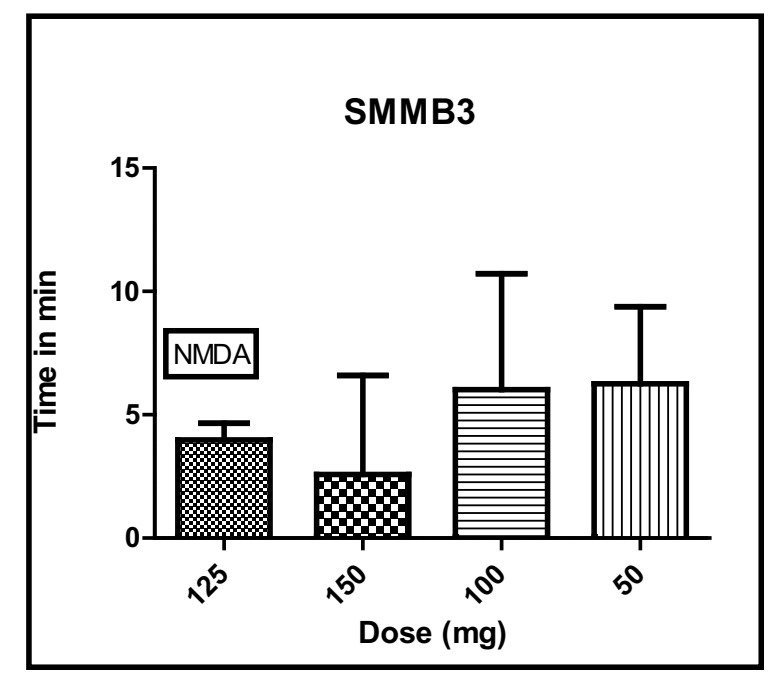

Figure 3: It shows one way ANOVA for inhibition of clonic convulsion of $\mathrm{SMMB}_{3}$ at different dose level
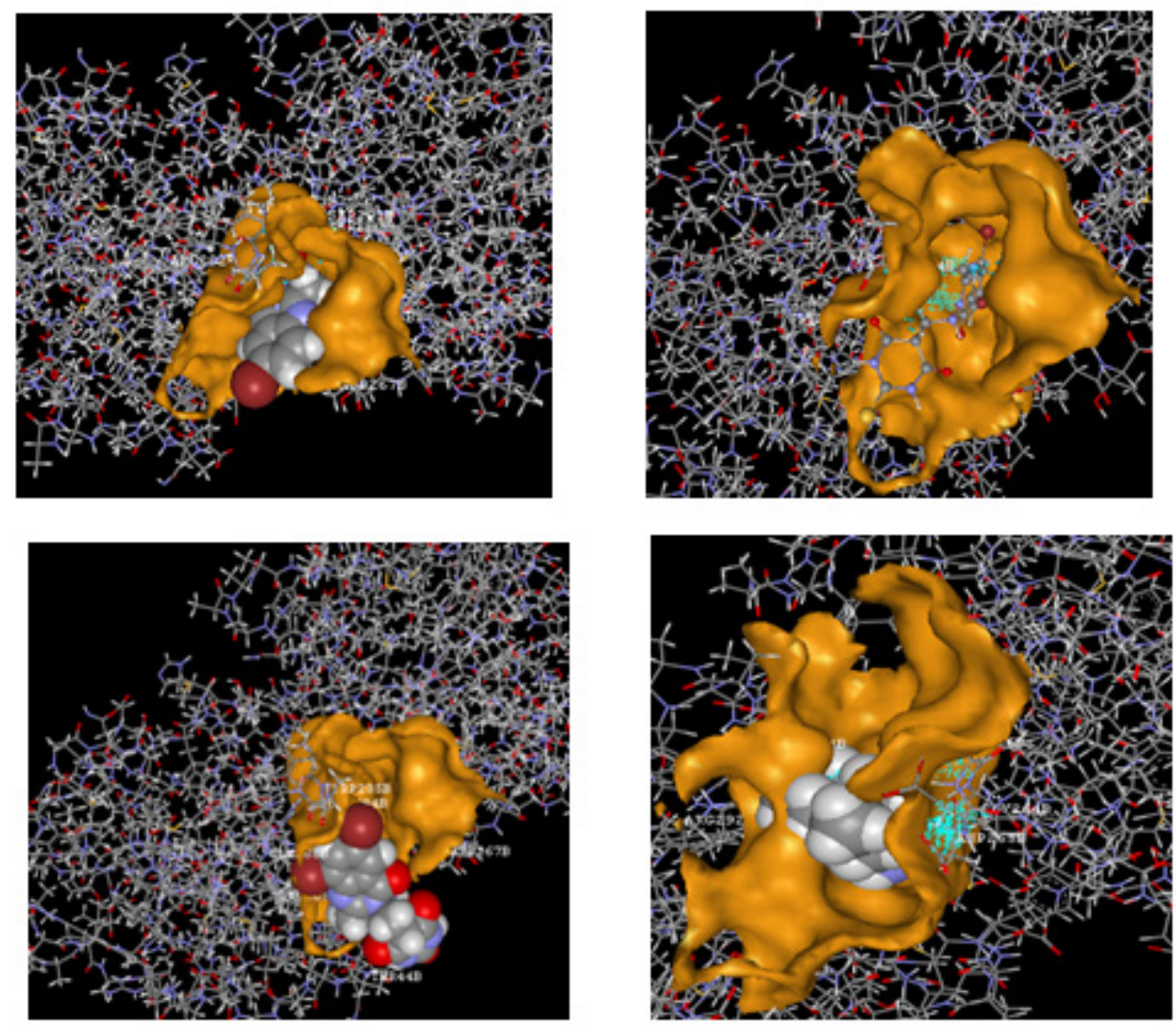

Figure 3a: CPK space fill model of SMMB1-3 and Std. memantine (posses of molecules with receptor and amino acid interaction)

is indicative of $88 \%, 96 \%$ and $84 \%$ chances of being anticonvulsant leads. ADME properties of these compounds were also found to be satisfactory. Limit for MDCK cell permeability is in the limit of less than 500 indicates medium permeability; all the compounds have Caco2 cell permeability in the range of middle permeability.
Compounds shown to have plasma protein binding in the range of more than $90 \%$ shown strongly bound. Thus the molecules $\mathrm{SMMB}_{1-3}$ were prioritized based on the basis of BAS \& ADME before actual synthesis. The results in this paper indicate that compounds $\mathrm{SMMB}_{2}$ and $\mathrm{SMMB}_{3}$ shown the existence of a ligand with receptor hydrogen bond 


\begin{tabular}{|c|c|c|c|c|}
\hline \multirow{2}{*}{ Control NMDA } & \multirow{2}{*}{$\begin{array}{c}\text { Standard } \\
\text { MEMANTINE }\end{array}$} & \multicolumn{3}{|c|}{ Doses $(\mathrm{mg} / \mathrm{kg})$} \\
\hline & & $150 \mathrm{mg} / \mathrm{kg}$ & $100 \mathrm{mg} / \mathrm{kg}$ & $50 \mathrm{mg} / \mathrm{kg}$ \\
\hline $3.2^{*}$ & 10.5 & 8.0 & 10 & 6.5 \\
\hline 3.5 & 12.5 & 7.5 & 8.5 & 7.2 \\
\hline 4.0 & 15.5 & 0.0 & 9.3 & 7.8 \\
\hline 5.0 & 9.8 & 0.0 & 8.3 & 8.5 \\
\hline 4.5 & 10.7 & 0.0 & 0.0 & 7.5 \\
\hline 3.7 & 9.8 & 0.0 & 0.0 & 0.0 \\
\hline $3.98 \pm 0.66$ & $11.43 \pm 2.1$ & $2.58 \pm 4.00$ & $6.017 \pm 4.7$ & $6.25 \pm 3.1$ \\
\hline $33.85 \%$ & $100 \%$ & $48.63 \%$ & $79.20 \%$ & $69.10 \%$ \\
\hline
\end{tabular}

interaction between an acceptor attached to the ligand and a hydrogen bond donor attached to the receptor shown good result compared with standard (Figure 3). SMMB showed the interaction with His127b, Ser131b, Ile133b, $\mathrm{SMMB}_{2}$ showed the interaction with Thr103b, Gly128b, Met132b and $\mathrm{SMMB}_{3}$ showed the interaction with Thr44b, Asp102b, His127b amino acids.

\section{Synthesis}

In synthetic scheme barbituric acid and thiobarbituric acid condensed with quinazolinone scaffold in presence of methanol and formaldehyde called as mannich base or mannich reaction.

The compounds were characterized on the basis of, TLC, Melting point, ${ }^{1} \mathrm{H}-\mathrm{NMR}$ and IR. The ${ }^{1} \mathrm{H}-\mathrm{NMR}$ showed characteristic peak at 4.2-4.4 ppm which is conclusive of the linkage between the thiobarbituric acid, barbituric acid and Quinazonlinone scaffolds.

\section{Pharmacological Screenings}

Synthesized compounds of series $\mathrm{SMMB}_{1-3}$ were evaluated for pharmacological screening by acute oral toxicity (AOT) and anticonvulsant activity on NMDA receptor.

AOT: According to OECD 425 guidelines based upon their AOT studies $\mathrm{SMMB}_{1-3}$ was administered orally at a dose of $700-2000 \mathrm{mg} / \mathrm{Kg}$ body weight. At AOT compounds were found to safe at $2000 \mathrm{mg} / \mathrm{kg}$ dose and can be considered as maximum safe dose of the compounds. For anti-convulsant activity proper dose was selected based upon the LD50 values obtained from AOT.

Anticonvulsant Screenings: NMDA induced convulsion model in which the $\mathrm{LD}_{50}$ of molecules were divided into three dose level and memantine was given orally as the standard or as antagonist. It was observed that as dose increases time of prolongation of convulsion and percentage of inhibition also increases while percentage of death decreases. $\mathrm{SMMB}_{3}$ showed the $\%$ potency of about $79.2 \%$, as compared with memnatine at a dose of $100 \mathrm{mg} / \mathrm{kg}$ (Table 7).

\section{CONCLUSION}

This research work concludes that, compounds were prioritized on the basis of the docking study by Vlife MDS 4.3 software. AOT was carried at a dose of 2000 $\mathrm{mg} / \mathrm{kg}$ on mice for determining the $\mathrm{LD}_{50}$ of compounds. Compounds $\mathrm{SMMB}_{3}$ showed potent anticonvulsant activity as NMDA receptor antagonist compared with standard as memnatine and can be considered as "Lead" for NMDA antagonism.

At conclusion, Mannich bases of barbituric acid and thiobarbituric acid were in silico designed, synthesized and pharmacologically evaluated. Compound $\mathrm{SMMB}_{3}$ showed potent anti-convulsant activity of $79.2 \%$ through NMDA receptor antagonism, as compared with memnatine. The compound can serve as future lead for anticonvulsant activity.

\section{ACKNOWLEDGEMENT}

We acknowledge the Board of College and University Development (BCUD), Savitribai Phule Pune University for funding the project vide sanction grant number $13 \mathrm{PH} 000882$.

\section{CONFLICT OF INTERESTS}

There are no conflicts of interests. 


\section{Highlights of Paper}

- NMDA Receptor is an important target for development and discovery of Anticonvulsants.

- A series of quinazolinones condensed with Barbiturates and thiobarbiturates/barbiturates was in silico prioritized, synthesized and pharmacologically screened for NMDA antagonism.

- Acute Oral Toxicity studies revealed LD50 dose of compounds and Compound SMMB3 was found safe at $2000 \mathrm{Mg} / \mathrm{Kg}$ dose and has $79.2 \%$ potentcy as compared with Memantine.

\section{Author Profile}

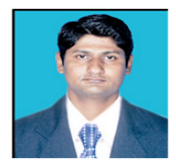

- Dr. Amit G. Nerkar: Presently working Associate Professor, Department of Pharmaceutical and Medicinal Chemistry, Sinhgad Institute's, Smt. Kashibai Navale College of Pharmacy (SKNCOP), Pune, Maharashtra affiliated to Savitribai Phule University of Pune. He has authored 26 research papers in SCl indexed journals, 42 research paper presentations in National and International Conferences, 2 books in press and 3 invited talks. Dr. Nerkar has 2 Research Grants from Central Govt. funding agencies and 1 from BCUD, Savitribai Phule University of Pune. At SKNCOP, he is in- charge Post Graduation department of Pharmaceutical and Medicinal Chemistry , Ex-Head Funding Assistance Cell and Academic and Research Co-ordinator for SKNCOP for SPPU.

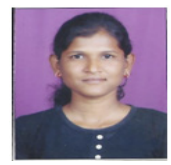

- Ms. Shweta Valvi: Presently working as Post Graduation (M.Pharm) Research Fellow in Department of Pharmaceutical and Medicinal Chemistry, Sinhgad Institute's Smt. Kashibai Navale College of Pharmacy, Pune, Maharashtra. Ms. Valvi has presented 08 papers in National and International Conferences.

\section{REFERENCES}

1. Lade KS, Nerkar AG, Sawant SD. In silico prioritization of some Quinazolinones for Anticonvulsant Activity. J. Pharm. Res. 2011; 4(8): $2800-2$.

2. Nerkar AG, Joshi PP, Mohite S, Singh S, More M, Chikhale HU, Sawant SD, et al. In silico Design, Synthesis and Pharmacological Screening of novel mono and di-bromo Quinazolinones derivatives as NMDA receptor antagonists for Anticonvulsant Activity. Int. J. Pharm. Pharm Sci. 2013; 5(1): 331-5.

3. Sahu M, Nerkar AG, Sawant SD. In silico Screening, Synthesis and Pharmacological Screening of Quinazolinones Containing Oxazepinone Ring as NMDA Receptor Antagonists for Anticonvulsant Activity: Part -I. J. Young. Pharmacist 2015; 7(1): 21-7.

4. Parasuraman S. Prediction of activity spectra for substances. $\mathrm{J}$ Pharmacol Pharmacother. 2011; 2: 52-3.

5. Molinospiration. Available in www.molinspiration.com [Last accessed on 10/07/2015].

6. www.bmdrc.com/04_product/01_preadmet.asp. [Last accessed on 05/06/2015].

7. Rajveer $\mathrm{CH}$, Swarnalatha $\mathrm{CH}$, Rathinaraj BS, Sudhrshini S. Synthesis of 6-bromo-Oxoquinazoline derivatives and their pharamcological activities. Int. J. Chem. Res. 2010; 1(1): 21-4.

8. Archana, Srivastava A, Kumar VK. Synthesis of some newer derivatives of substituted quinazolinonyl-2-oxo/thiobarbituric acid as potent anticonvulsant agents. Bioorg. Medi. Chem. 2004; 12:
1257-64.

9. Wolfe JF, Rathman TL, Sleevi MC. Synthesis and anticonvulsant activity of some new 2-substituted 3-aryl-4(3H)-quinazolinones. J. Med. Chem. 1990; 33(1): 161-6.

10. Mondal P, Banerjee M, Jana S, Bose A. Synthesis and evalution of 1,3-di substituted schiffs base, mannich base and spiro isatin derivatives. JYP. 2010; 2(2): 169-72.

11. Parasuraman S. Toxicological screening. J Pharmcol. Pharmacother. 2011; 2(2): 74-9.

12. OECD Guideline for testing of chemical 425, Adopted; 2001 December 17.

13. Kulkarni SK. Pharmacology of Central Nervous System, In Handbook of Experimental Pharmacology. Vallabh Prakashan, $3^{\text {rd }}$ edition; 1984. 143-55.

14. Ghosh MN. Toxicity studies, Fundamentals of Experimental pharmacology. SK Ghosh and other publication, $4^{\text {th }}$ edition; 1965. 164-6.

15. Turner RA. Anticonvulsants. Screening Methods in Pharmacology. Academic; 1965. 164-6.

16. Skolnick P, Miller R, Young A, Boje K, Trullas R. Chronic treatment with 1-aminocyclopropanecarboxylic acid desensitizes behavioral responses to compounds acting at the N-methylD-aspartate receptor complex. Psychopharmacology 1992; 107(4): 489-96. 